\title{
Immunoassay of Oryzacystatin Occurring in Rice Seeds during Maturation and Germination
}

\author{
Hiroto Kondo, Keiko Abe and Soichi AraI \\ Department of Agricultural Chemistry, The University of Tokyo, \\ Bunkyo-ku, Tokyo 113, Japan
}

Received June 1, 1989

\begin{abstract}
Oryzacystatin, a proteinaceous cysteine proteinase inhibitor (cystatin) from rice seeds and probably the first well-defined cystatin superfamily member of plant origin, was immunologically investigated for its occurrence in rice seeds during maturation and germination. The enzyme-linked immunosorbent assay (ELISA) using anti-oryzacystatin Immunoglobulin $G$ showed that all the investigated 23 cultivars of rice, Oryza sativa L. japonica, contained oryzacystatin at $1 \sim 4 \mathrm{mg} \%$ in their seeds. Particularly, oryzacystatin levels were high in precocious cultivars and low in sticky rice cultivars. The use of the ELISA method for the representative rice cultivar, Nipponbare, gave the result that in the seed maturation process, oryzacystatin was synthesized in precedence to total seed protein. In the germination process, oryzacystatin tended to decrease in accordance with degradation of total seed protein.
\end{abstract}

Oryzacystatin is a proteinaceous cysteine proteinase inhibitor, i.e., cystatin, which we found in rice seeds and purified to define its general properties. ${ }^{1,2)}$ We have also cloned and analyzed a cDNA encoding oryzacystatin to deduce its amino acid sequence. ${ }^{3)}$ Our recent work has dealt with expression of the cDNA and its deletion fragments in Eschrichia coli to clarify the relationship between the primary structure of oryzacystatin and its activity for inhibiting the action of a cysteine proteinase (papain). ${ }^{4}$ These studies suggest that oryzacystatin could be classified as a member of the cystatin superfamily ${ }^{5)}$ and also provide new information useful to estimate the structureactivity relationship of mammalian cystatins. ${ }^{6 \sim 14)}$ Oryzacystatin can thus be recognized as the first well-defined cystatin of plant origin, but its distribution in rice cultivars and its features in the seed maturation-germination process are not fully understood. This study aims at elucidating these respects, primarily by the enzyme-linked immunosorbent assay (ELISA) with a polyclonal antibody to oryzacystatin.

\section{Materials and Methods}

Rice cultivars. Twenty three cultivars of rice, Oryza sativa L. japonica, were investigated; all of them were of 1985-year harvests in the Experimental Farm at the University of Tokyo.

Preparation of mature and immature seeds. Rice ears were sampled every week during the maturation period after flowering. Approximately 170 mature seeds and an equivalent amount of immature seeds were freeze-dried and weighed. Each of the freeze-dried products was homogenized with $30 \mathrm{ml}$ of $25 \mathrm{~mm}$ phosphate buffer $(\mathrm{pH} 7.0)$ containing $0.15 \mathrm{M} \mathrm{NaCl}$, and centrifuged at $7000 \times g$ for $20 \mathrm{~min}$. The supernatant was immediately heated at $80^{\circ} \mathrm{C}$ for $10 \mathrm{~min}$ to inactivate any proteases that might exist. The supernatant was then cooled to $4^{\circ} \mathrm{C}$ and filtered to obtain a sample for the ELISA method.

Preparation of rice seeds in the course of germination. Rice seeds (Nakate-shinsenbon harvested in 1985) were germinated in wet vermiculite soil at $37^{\circ} \mathrm{C}$ without light. Approximately 150 seeds were sampled every two days in the course of germination after the budding and treated in the same way as the mature or immature seeds above.

Measurement of total protein. An appropriate amount of rice seeds, mature or immature, was freeze-dried and analyzed for nitrogen. The total protein content of the seeds was obtained by multiplying the nitrogen amount by 6.25. Germinating seeds were also analyzed for nitrogen and their total protein contents were calculated similarly. 


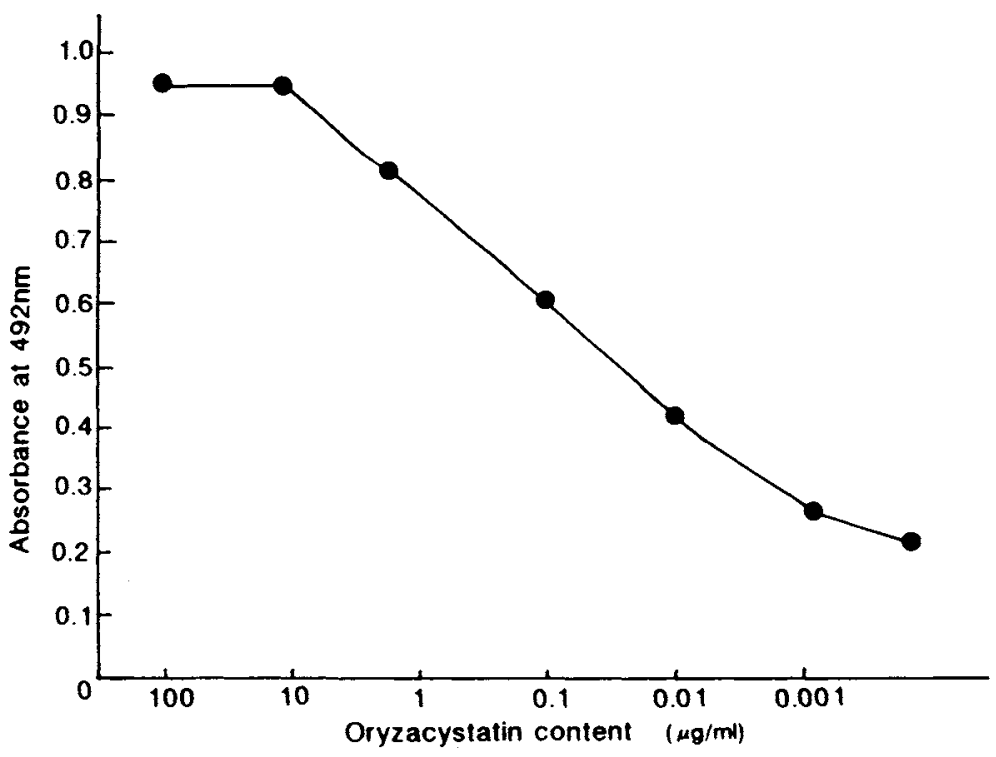

Fig. 1. Calibration Curve for the Oryzacystatin Content.

Various amounts of a purified oryzacystatin solution were measured by the ELISA method using the antioryzacystatin IgG. After the reaction (see Materials and Methods), the intensity of the fluoresence developed was measured with a spectrophotometer at $492 \mathrm{~nm}$.

Purification of oryzacystatin. A purified sample of oryzacystatin was prepared from mature seeds of the cultivar Nipponbare as described. ${ }^{2)}$ Both the electrophoretical homogenity of the purified sample and its sufficient papain-inhibitory activity were confirmed as in our previous study. ${ }^{2)}$

Activity assay. A recrystallized preparation of papain (EC 3.4.22.2) was obtained from the Sigma Chemical $\mathrm{Co}$. and used to assay the inhibitory activity of oryzacystatin. For the assay, $N$-benzoyl-DL-arginine-2-naphthylamide (BANA) was used as the substrate of papain and a decrease in its BANA-hydrolyzing activity due to oryzacystatin was quantified as reported. ${ }^{15)}$

Preparation of antibody. A female rabbit of the New Zealand white strain, weighing $3.1 \mathrm{~kg}$, was used. The rabbit received an injection of $200 \mu \mathrm{g}$ of oryzacystatin dissolved in $2 \mathrm{ml}$ of a $50: 50$ mixture of $10 \mathrm{~mm}$ phosphate buffer ( $\mathrm{pH} 7.1)$ containing $10 \mathrm{~mm} \mathrm{NaCl}$ and Freunds' complete adjuvant. Two weeks after boosting, the rabbit was killed to collect the systemic blood for preparation of the serum. Immunity was then confirmed by the Ouchterlony double-diffusion method. The entire amount of blood was left for $24 \mathrm{hr}$ at room temperature and then centrifuged for $15 \mathrm{~min}$ at $2000 \times \mathrm{g}$. The supernatant was immediately mixed with ammonium sulfate to obtain a precipitate which formed at lower than $30 \%$ saturation with respect to this salt. The precipitate was dissolved in $5 \mathrm{ml}$ of $0.015 \mathrm{M}$ Tris-phosphate buffer, pH 8.3 (buffer A) and dialyzed against the same buffer. The resulting nondiffusible fraction was put on a DEAE-Sephadex A-50 column $(1.5 \times 15 \mathrm{~cm})$ equilibrated with buffer $A$. The through fraction was taken as an anti-oryzacystatin Immunoglobulin $\mathrm{G}$ sample. It was stored at $-20^{\circ} \mathrm{C}$ until used.

ELISA for quantification of oryzacystatin. ELISA method was used for the quantitative analysis of oryzacystatin. Three hundred $\mu \mathrm{l}$ of each sample solution was used for this assay. Oryzacystatin occuring in the sample was thus quantified using a calibration curve that had been made with varying amounts of purified oryzacystatin (Fig. 1).

\section{Results}

\section{Anti-oryzacystatin $\operatorname{Ig} G$ and its purity}

Two weeks after boosting for immunization of a rabbit with oryzacystatin, a clear subsidence line was observed by the Ouchterlony double-diffusion test. Six weeks after the first immunization, almost the entire amount of the systemic blood was taken as a polyclonal antibody serum to purify the anti-oryzacystatin IgG by DEAE-Sephadex A-50 chromatography. The through fraction was found to be electrophoretically homogeneous (Fig. 


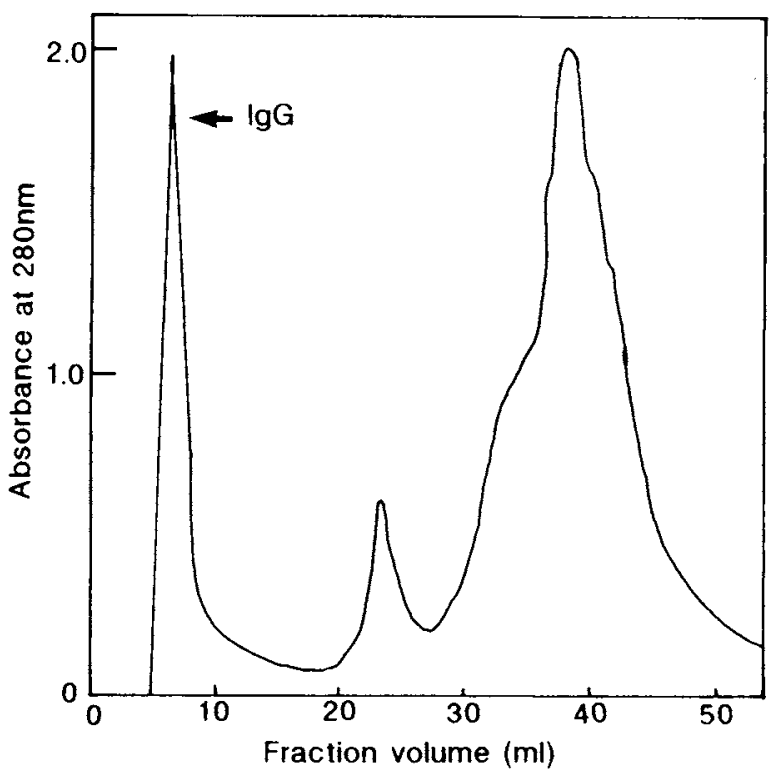

Fig. 2. Elution Profile of Polyclonal Antibody after Passage through DEAE-Sephadex Chromatography. The sample solution (see Materials and Methods) was put on a DEAE-Sephadex column previously equilibrated with $0.015 \mathrm{M}$ phosphate buffer $(\mathrm{pH} 8.0$ ). After being washed with the same buffer, the column was eluted with a density linear gradient from $0.015 \mathrm{M}$ to $0.3 \mathrm{M}$ to collect fractions ( $1 \mathrm{ml}$ each). The polyclonal antibody fraction is indicated by arrow.

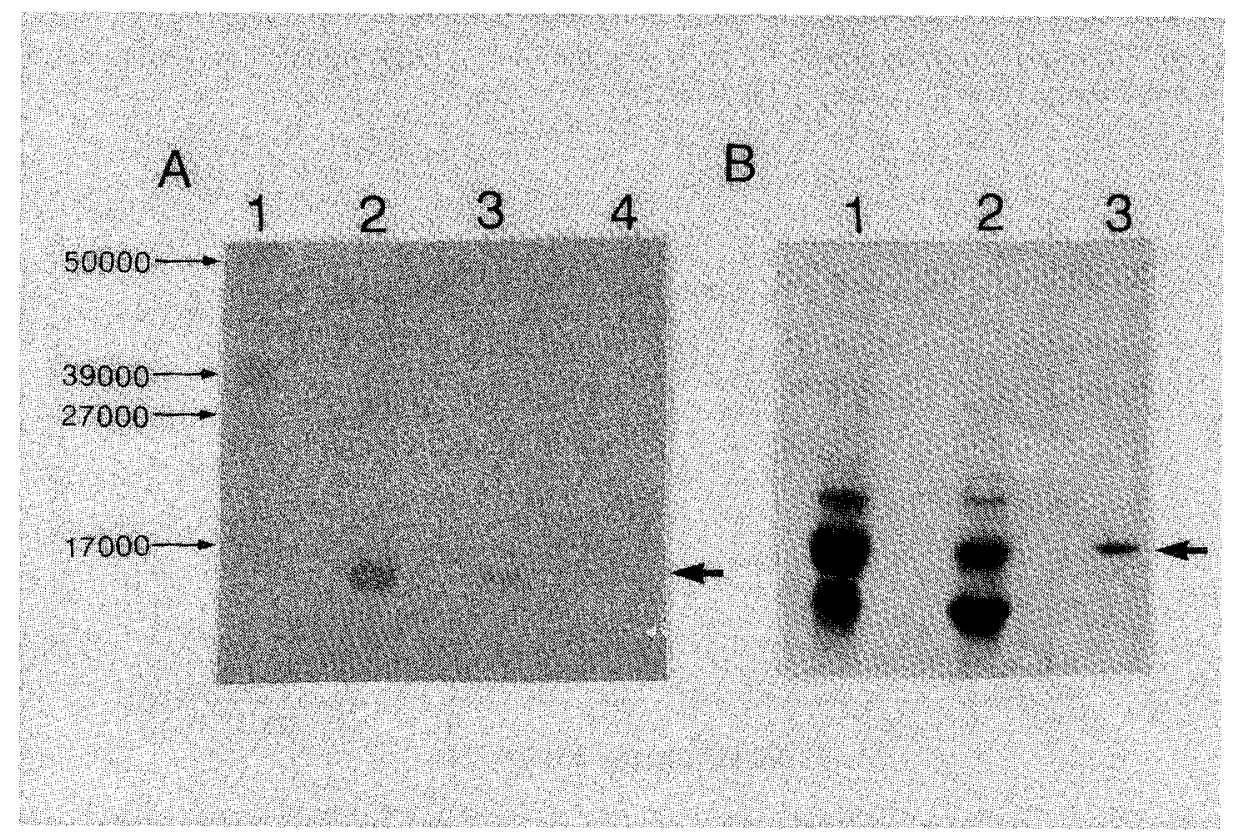

Fig. 3. Western-blotting Analysis of the Oryzacystatin.

Panel A shows the immunoblotting analysis. The size-markers shown in lane 1: 17,000 (lysozyme), 27,000 (soybean trypsin inhibitor), 39,000 (carbonic anhydrase) and 50,000 (ovalbumin). Lane 2, purified oryzacystatin; lane 3, partially purified oryzacystatin; and lane 4, crude extraction of rice seeds. Panel B shows SDSPAGE stained with Coomassie Brilliant Blue R-250. Lane 1, crude extraction of rice seeds; lane 2, partially purified oryzacystatin; and lane 3 , purified oryzacystatin. 
Table I. Amounts of Oryzacystatin in Various Rice Cultivars in Relation to Thetr Protein Contents

\begin{tabular}{lccc} 
Cultivar & $\begin{array}{c}\text { Oryzacystatin } \\
(\mu \mathrm{g} / \mathrm{seed})\end{array}$ & $\begin{array}{c}\text { Oryzacystatin/weight } \\
(\mathrm{mg} / 100 \mathrm{~g} \text { seed })\end{array}$ & $\begin{array}{c}\text { Protein } \\
(\mathrm{mg} / \mathrm{seed})\end{array}$ \\
\hline Sorachi & 200.0 & 2.54 & 626.0 \\
Yuukara & 220.0 & 2.75 & 469.0 \\
Ishikari & 200.0 & 2.99 & 507.5 \\
Musashi-kogane & 85.9 & 1.10 & - \\
Kinmaze & 140.7 & 1.78 & 803.0 \\
Arborio & 183.7 & 1.48 & - \\
Nishihomare & 115.6 & 1.59 & - \\
Toyotama & 183.7 & 2.59 & 455.0 \\
Deruta & 183.7 & 1.86 & 535.0 \\
Murasakiine & 115.6 & 1.50 & 439.7 \\
Saikei & 140.7 & 2.17 & - \\
Daikokuichigoh & 120.0 & 3.97 & - \\
Senichi & 85.9 & 1.48 & - \\
Taninakazairaiichigo & 85.9 & 2.00 & 429.0 \\
Shoukei & 220.0 & 3.59 & 567.0 \\
Sasanishiki & 140.7 & 2.10 & 621.0 \\
Aikoku & 220.0 & 3.50 & 473.0 \\
Perenius & 60.0 & 1.13 & - \\
Nipponbare & 85.9 & 1.05 & - \\
Taiwanmochi & 85.9 & 1.22 & - \\
Saitamamochi & 85.9 & 1.21 & - \\
Mangetsumochi & 140.7 & 1.93 & -2.0 \\
Kankokumochi & 85.9 & 1.26 & - \\
\hline
\end{tabular}

300 grains of each rice seed were used for these analyses by the ELISA method. The weight of each seed was measured after freeze drying.

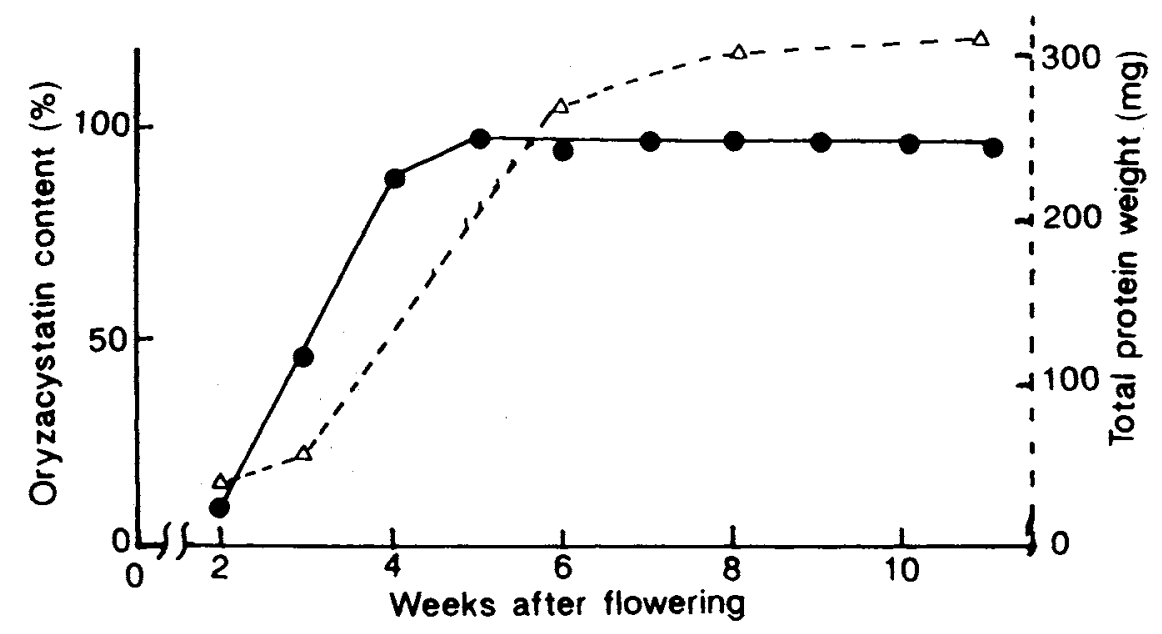

Fig. 4. Changes in Oryzacystatin and Total Protein Contents of Rice Seeds in the Maturation Process. Prepared samples (see Materials and Methods) were analyzed every two weeks after flowering with the use of ELISA method. The oryzacystatin content of rice seeds, 5 weeks after flowering, was defined as $100 \%$ and the rates of oryzacystatin contents in other cases were calculated by comparison. $(\bullet)$, oryzacystatin content; $(\triangle)$, total protein content. 


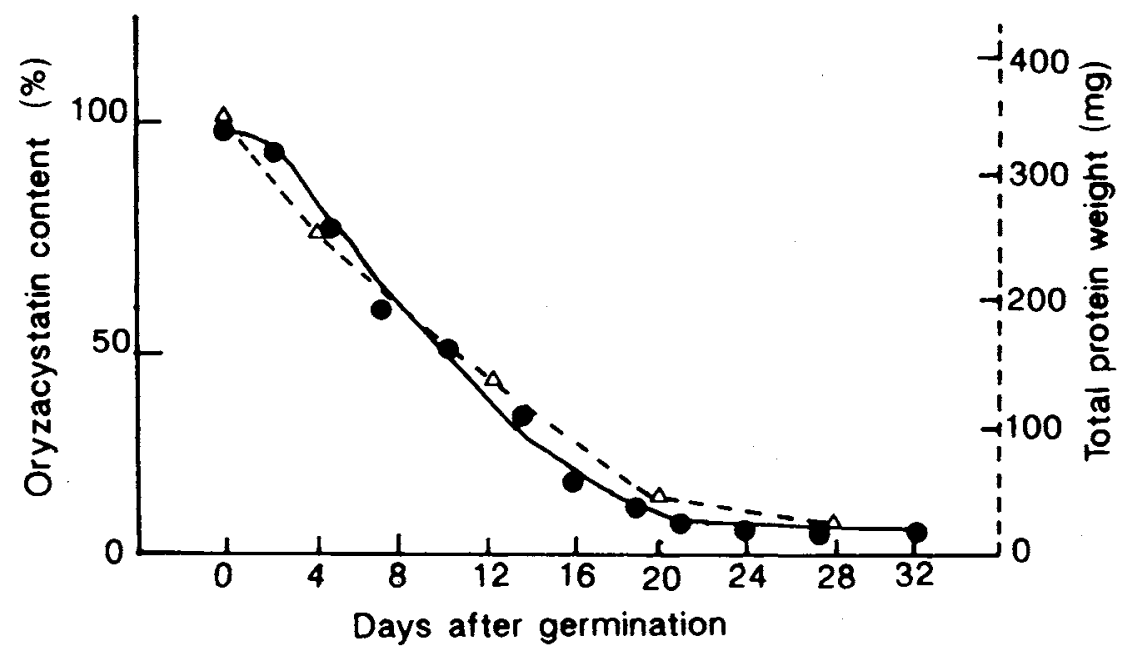

Fig. 5. Change in Oryzacystatin and Total Protein Contents of Rice Seeds in the Germination Process. Prepared samples (see Materials and Methods) were analyzed every two days after germination by the ELISA method. The oryzacystatin content of rice seeds before germination was defined as $100 \%$. ( ), oryzacystatin content; $(\triangle)$, total protein content.

2), containing $\mathrm{IgG}$ at a level of $1.28 \mathrm{mg} / \mathrm{ml}$. Western-blotting analysis showed that among all rice proteins only oryzacystatin cross-reacted with the antiserum (Fig. 3).

Oryzacystatin contents of various cultivars

We used the anti-oryzacystatin IgG to measure of oryzacystatin in mature seeds of 23 rice cultivars (Table I). The measurement showed that oryzacystatin was generally contained at a level of $1 \sim 4 \mathrm{mg} \%$ in seeds. In particular, the oryzacystatin level was high in precocious cultivars such as "Sorachi" and "Yukara," and low in sticky rice cultivars such as "Saitamamochi," "Kankokumochi" and "Taiwanmochi."

Synthesis of oryzacystatin in seeds during maturation

The application of anti-oryzacystatin IgG to mature and immature seeds of the cultivar Nipponbare demonstrated that, during the time from 2 weeks to 4 weeks after flowering, oryzacystatin was synthesized rapidly and its level increased in a linear fashion (Fig. 4). The level reached a plateau 5 weeks after flowering and was constant for another 6 weeks or longer. The feature observed for the oryzacystatin synthesis was quite different from that found for the total protein formation which started at 3 weeks and ended at 10 weeks from the flowering stage (Fig. 4).

\section{Degradation of oryzacystatin in seeds during germination}

A similar immunoassay showed that oryzacystatin was degraded as rapidly as the total protein in seeds during germination; a parallelism existed between the degradation of oryzacystatin and that of the total protein (Fig. 5).

\section{Discussion}

In this study we obtained an antioryzacystatin antibody which cross-reacted only with oryzacystatin among a variety of proteins in rice seeds. Unlike complicated quantitative analysis based on the papaininhibitory activity assay, ${ }^{15)}$ the ELISA method with the antibody allowed easier measurement of oryzacystatin in rice seeds.

Using this method, we found the quantity of oryzacystatin was higher in precocious cul- 
tivars relative to their total protein contents. We also observed changes in amounts of oryzacystatin during maturation and germination. The results obtained for the maturation process (Fig. 4) are consistent with our previous observation that the mRNA encoding oryzacystatin is synthesized earlier than the mRNA encoding glutelin, a major rice seed storage protein. It is thought that oryzacystatin might be synthesized in advance to prevent the storage protein from being degraded by some cysteine proteinase. Actually, rice seeds have a cysteine proteinase which is effectively inhibited by oryzacystatin. ${ }^{16)}$

We have also reported the nucleotide sequence of oryzacystatin gene ${ }^{17)}$ and found that there is no sequence homology in the 5'upstream region between the oryzacystatin gene and the glutelin gene. The promoter region of the oryzacystatin gene may have a nucleotide sequence which is involved in timespecific expression of oryzacystatin in rice seeds. The oryzacystatin promoter may act to enhance the expression of oryzacystatin in the early stage of maturation and to regulate its expression thereafter.

Further knowledge about the expression of oryzacystatin and that of proteases involved in its degradation during germination will be obtained if their gene structures are investigated in more detail. The antibody produced in this study would be useful to confirm the process of oryzacystatin gene expression.

\section{References}

1) K. Abe, H. Kondo and S. Arai, Agric. Biol. Chem., 49, 3349 (1985).

2) K. Abe, H. Kondo and S. Arai, Agric. Biol. Chem., 51, 2763 (1987).

3) K. Abe, Y. Emori, H. Kondo, K. Suzuki and S. Arai, J. Biol. Chem., 35, 16793 (1987).

4) K. Abe, Y. Emori, H. Kondo, K. Suzuki and S. Arai, J. Biol. Chem., 263, 7655 (1988).

5) J. A. Barrett, D. N. Rawlings, E. M. Davies, W. Machleidt, G. Salvesen and V. Turk, in "Proteinase inhibitors," ed. by A. J. Barrett and G. Salvesen, Elsevier, Amsterdam-New York-Oxford, 1986, pp. $515 \sim 569$.

6) W. Machleidt, U. Borchart, H. Fritz, J. Brzin, A. Ritonja and V. Turk, Hoppe-Seyler's Z. Physiol. Chem., 364, 1481 (1983).

7) A. Ritonja, W. Machleidt and A. J. Barrett, Biochem. Biophys. Res. Commun., 131, 1187 (1985).

8) K. Takio, E. Kominami, Y. Bando, N. Katunuma and K. Titani, Biochem. Biophys. Res. Commun., 121, 149 (1984).

9) K. Takio, E. Kominami, N. Wakamatsu, N. Katsunuma and K. Titani, Biochem. Biophys. Res. Commun., 115, 902 (1983).

10) A. Grubb and H. Lofberg, Proc. Natl. Acad. Sci. U.S.A., 79, 3024 (1982).

11) S. Isemura, E. Saitoh, K. Sanada, M. Isemura and S. Ito, J. Biochem., 96, 1311 (1984).

12) M. Hirado, S. Tsunasawa, F. Sakiyama, M. Ninobe and S. Fujii, FEBS Lett., 186, 41 (1985).

13) V. Turk, J. Brzin, M. Longer, A. Ritonja, M. Eropkin, U. Borchart and W. Machleidt, HoppeSeyler's Z. Physiol. Chem., 364, 1487 (1983).

14) I. Ohkubo, K. Kurachi, T. Takasawa, H. Shiokawa and M. Sasaki, Biochemistry, 23, 5691 (1984).

15) A. J. Barrett, Anal. Biochem., 447, 280 (1972).

16) K. Abe, H. Kondo and S. Arai, Agric. Biol. Chem., 51, 1509 (1987).

17) H. Kondo, Y. Emori, K. Abe, K. Suzuki and S. Arai, Gene, 81, 259 (1989). 